\title{
THE ROLE OF THE SUPERVISION AND OBSERVATION JUDGE ON GUIDANCE FOR INMATES
}

\author{
Bunyamin Muhammad Yafid ${ }^{1 *}$, Abd. Kahar Muzakkir ${ }^{2}$ \\ ${ }^{1}$ Sekolah Tinggi Agama Islam Darud Da'wah Wal Irsyad, Sidenreng Rappang \\ ${ }^{2}$ President Director, CV. Social Politic Genius (SIGn), Indonesia \\ *Correspondence Author: Bunyamin Muhammad Yafid \\ Email Correspondence: annurmaarif17@gmail.com
}

\begin{abstract}
Judicial institutions, as law enforcement agencies in the Criminal Justice System, are a foundation of hopes for justice seekers, as based on Article 2 section (4) of Law No. 48 of 2009, regulates that "the Court is done simply, quickly, and at a low cost". Therefore, this study aims to determine the implementation of the Supervision and Observation Judge's role and the obstacles that affect the Supervision and Observation Judge's performance in implementing Court Decisions in the Penitentiary. This study uses two types of research, namely normative legal research and empirical legal research. This research was conducted at the Makassar Class I Penitentiary and the Makassar Class IA District Court. The types of data used in this study include primary data and secondary data. The data that has been collected is then processed descriptively qualitatively. The results of the study concluded that the implementation of the role of the Supervision and Observation Judge in the implementation of the decision of the Makassar Class IA District Court at the Makassar Class I Penitentiary has not run optimally, because between The Supervision and Observation Judge and the Head of the Penitentiary rarely meet and discuss guidance issues for Inmates at the Penitentiary. The obstacles in implementing the role of the Supervision and Observation Judge at the Penitentiary include the problem of insufficient funds available for operational supervision and observation and the absence of special staff to assist the Supervision and Observation Judge in recording their Inmates. Therefore, more specific implementing regulations are needed to certify that the judgment is being properly executed and under the laws and regulations in Indonesia. Furthermore, there is a need for effective cooperation between the Supervision and Observation Judge and the Penitentiary Officers, who must always coordinate as one unit in an integrated Criminal Justice System.
\end{abstract}

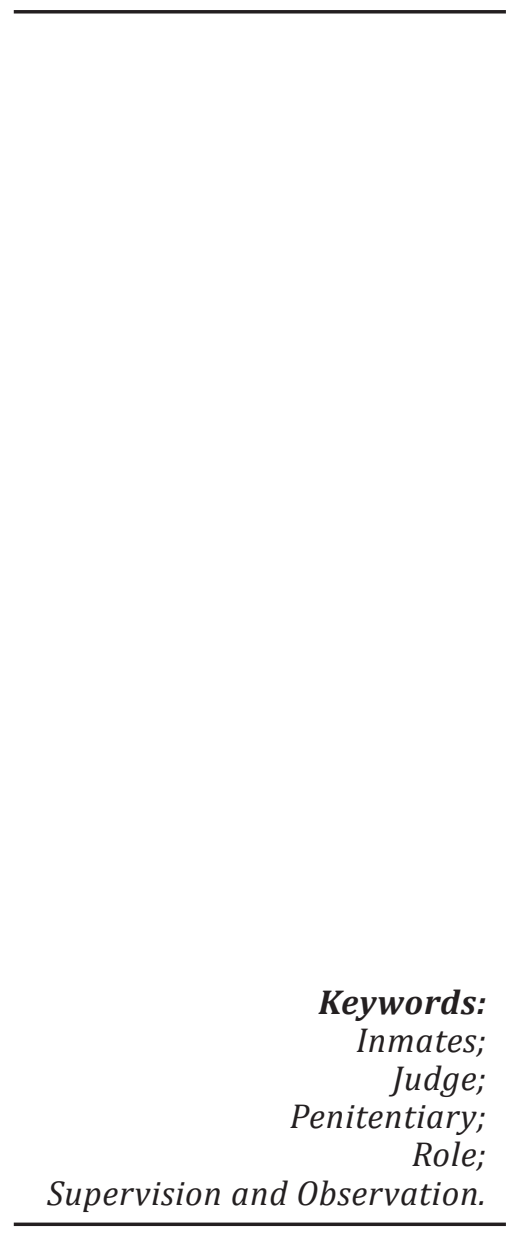

Keywords: mates; tiary; Role;

\section{(c) (1) (2)}

Articles with open access under a CC BY SA-4.0 license 


\section{INTRODUCTION}

As the rule of law, Indonesia has three basic principles, namely (Pratama, W. A., 2019):

1. Supremacy of law;

2. Equality before the law; and

3. The due process of law in a way that is not against the law.

Furthermore, every rule of law has characteristics, namely (Mahmud, Y., et al., 2019):

1. Guarantee of protection of human rights;

2. Judicial power or an independent judiciary; and

3. Legality in the sense of law, namely that both the government/state and citizens acting must be based on through the law.

One of the state institutions that play the role of legal protection is the Penitentiary. The objectives and duties of protecting and fostering Inmates. According to Tjahjati, E. (2012), that:

"Guidance for Inmates, which is to provide legal counselling to make Inmates reach a high level of legal awareness. Besides, as a member of society, Inmates is aware of their rights and obligations to uphold law and justice, protection of human dignity, order, tranquillity, legal certainty, and the formation of every Indonesian behaviour citizen who obeys the law."

Furthermore, the role of the Supervision and Observation Judge on guidance for Inmates, according to Taufiq, A. I. (2016), that "to ensure that the Prosecutor as executor has implemented the Court Decision, which has permanent legal force (inkracht)".

In connection with the implementation of the Supervision and Observation Judge's role on guidance for Inmates, Susansi, E. (2019) also has her conclusions, that:

"The Supervision and Observation Judge of guidance for Inmates' supervisory function ensures the protection of the Inmates' human rights; provide legal certainty guarantees for the implementation of the Judge's Decision; and guaranteed guidance for friends in the context of social reintegration in the community. Supervision and observation are broadly focused on Inmates' guidance and protection so that they are treated humanely. In addition, ensuring the provision of skills is in accordance with Inmates' interests and talents to benefit him and his family."

As for the elements of the rule of law, according to Soepiadhy, S. (2008), namely:

1. There is recognition of guarantees of human rights and citizens of the state;

2. There is a distribution of power;

3. In carrying out its duties and obligations, the government must be based on applicable law, both written and unwritten;

4. The existence of judicial power in exercising its power is independent, meaning that it is independent of government power and other powers. 
Judicial institutions, as law enforcement agencies in the Criminal Justice System, are a foundation of hopes for justice seekers, as based on Article 2 section (4) of Law of the Republic of Indonesia Number 48 of 2009 on the Judicial Powers (hereinafter referred to as Law No. 48 of 2009), regulates that "the Court is done simply, quickly, and at a low cost".

Normatively, Judges are given the freedom by law to Judge according to their beliefs without being influenced by anyone (Suherman, A., 2019). Judges are free to decide cases based on their thoughts and conscience and are also free from extra-judicial interference. All interference in judicial affairs by other parties outside the judicial power is prohibited, except in matters stated in the laws and regulations (Syamsudin, M., 2011).

However, the District Court faces various problems related to the Supervision and Observation Judge's role. In addition to carrying out the role of a special Judge for supervision and observation of Inmates in the Penitentiary, it still serves as an active Judge who handles and adjudicates cases (Nasrullah, N., 2020). Therefore, Judges who act as the Supervision and Observation Judge often have the reason for not having time to supervise and observe the Penitentiary guidance process (Taufiq, A. I., 2016).

Besides, the Supervision and Observation Judge in supervising Court Decisions is rarely carried out with Penitentiary Officers or with Inmates. Meanwhile, based on the Circular of the Supreme Court of the Republic of Indonesia Number 7 of 1985 on Task Implementation Instructions of the Supervision and Observation Judge (hereinafter referred to as the Supreme Court Circular No. 7 of 1985), regulates that:

"The Supervision and Observation Judge conducts a check on the spot at least once every three months to the Penitentiary to check the accuracy of the minutes of implementing Court Decisions signed by the Prosecutor, Head of Penitentiary, and Inmates."

Therefore, Muladi in Mys (2011) suggested that:

"We recommend that the articles regarding the Supervision and Observation Judge in Law No. 8 of 1981 on the Code of Criminal Procedure is abolished or omitted. So far, the Supervision and Observation Judge has not run optimally. The Supervision and Observation Judge's role in the Penitentiary system seems to place Penitentiary Officers under the Judge. Simultaneously, the Penitentiary is a subsystem that is equivalent to other subsystems in the Integrated Criminal Justice System, including Police, Prosecutors and Judges."

Based on the description above, this study aims to determine the implementation of the Supervision and Observation Judge's role and the obstacles that affect the Supervision and Observation Judge's performance in implementing Court Decisions in the Penitentiary. 


\section{METHOD}

This study uses two types of research, namely normative legal research and empirical legal research. Normative legal research includes research on legal principles, legal systematics, legal history, and legal comparisons (Qamar, N., et al., 2017). Meanwhile, empirical legal research is research that views law in its social context (Sampara, S. \& Husen, L. O., 2016), particularly in relation to the Supervision and Observation Judge's role in implementing Court Decisions in the Penitentiary. This research was conducted at the Makassar Class I Penitentiary and the Makassar Class IA District Court, by Bunyamin Muhammad Yafid, in 2016. The population in this research, including:

1. The Supervision and Observation Judge of the Makassar Class IA District Court;

2. Officers of the Makassar Class I Penitentiary;

3. Inmates of the Makassar Class I Penitentiary; and

4. Former Inmates.

The types of data used in this study include:

1. Primary data is data sourced from respondents based on population determination;

2. Secondary data is data that comes from tracing legal literature materials, in the form of official documents in related agencies, laws and regulations, references, legal articles, legal encyclopedias, as well as from official texts or publications. The primary legal materials as secondary data used in this study consist of:

a. Law No. 8 of 1981 on the Code of Criminal Procedure;

b. Law No. 12 of 1995 on Correctional;

c. Government Regulation No. 99 of 2012 on the Second Amendment to Government Regulation Number 32 of 1999 on Terms and Procedures for the Exercise of Correctional Assisted Residents Rights;

d. Decree of Minister of Justice No. M.02-PK.04.10 of 1990 on Guidance Pattern Inmates/Prisoners; and

e. Supreme Court Circular No. 7 of 1985 on Task Implementation Instructions of the Supervision and Observation Judge.

Data collection techniques in this study, namely as follows:

1. Observation, which is done by directly seeing the activities of the Inmates in the Penitentiary;

2. Interview, namely conducting direct interviews with respondents related to the problems studied in this study;

3. Documentation, done by officially requesting documents to the relevant agencies;

4. Literature study, carried out by taking an inventory, reading and analyzing primary legal materials.

The data that has been collected is then processed descriptively qualitatively. The analysis method is carried out by systematically identifying and linking the provisions contained in the primary legal material. 


\section{RESULTS AND DISCUSSION}

The research results describe that every Supervision and Observation Judge has been given the task of knowing the implementation of Court Decisions made by law enforcement officials and the Penitentiary. Therefore, the Supervision and Observation Judge must go directly to the Penitentiary because the Inmates are people who have been legally deprived of their rights and freedoms. Besides, Inmates must still receive justice in accordance with their position as someone who has been found guilty according to the law (Suhariyanto, B., 2017). This situation does not mean that the Inmates who are serving sentences in the Penitentiary do not have rights that need to be protected as human beings who have human rights. However, their rights that are limited by law must be given properly and later used as a joint evaluation and must be followed up together.

The Supervision and Observation Judge conducts supervision to obtain assurance that Court Decisions are carried out properly (Dewi, A. A. I. M. C., 2012). In the observation, The Supervision and Observation Judge observes the Inmates during their prison period, especially regarding their behaviour and the Penitentiary Officers' treatment towards their Inmates themselves. Thus, the Judge will be able to know the extent to which the Court's verdict shows the good and bad results of the Inmates concerned, but it is also important for research that is useful for criminalization.

Furthermore, this is reinforced by the need for supervision and implementation of Court Decisions based on Article 54 section (1) of Law No. 48 of 2009, which regulates that "the Implementation of Court Decisions in criminal cases carried out by the Prosecutor". As for based on Article 55 of Law No. 48 of 2009, regulates that:

(1) The Court's Head is obliged to supervise the implementation of Court Decisions that have permanent legal force.

(2) Supervision of the implementation of Court Decisions as referred to in section (1) is carried out in accordance with laws and regulations.

Suppose we pay attention to the function of the role carried out by The Supervision and Observation Judge. In that case, this condition is closely related to the function of the role carried out by the Penitentiary in order to guide the Inmates.

Based on Article 277 of Law of the Republic of Indonesia Number 8 of 1981 on the Code of Criminal Procedure (hereinafter referred to as Law No. 8 of 1981), regulates that:

(1) In every Court there must be a Judge who is given the special duty of assisting the head in carrying out the supervision and observation with regard to judgments that impose penalties depriving liberty.

(2) The Judge as intended by section (1) who shall be called the Judge for supervision and observation, shall be assigned by the Head of the Court for at most two years. 
Based on Article 280 section (1) of Law No. 8 of 1981, regulates that "the Judge for supervision and observation shall exercise supervision in order to obtain certainty that the judgment is being properly executed".

The role of the Supervision and Observation Judge is only a secondary task, not the main task, so a District Court Judge who is appointed as The Supervision and Observation Judge is not exempted from the main task of examining and adjudicating criminal and civil cases, staff appointed to assist The Supervision and Observation Judge. Supervision and Observation Judges still have to carry out their basic daily tasks. In the implementation mechanism, the Supervision and Observation Judge's role is currently seen as merely fulfilling administrative duties (fulfilling the obligation to make reports). So it has not touched deeply on the substance of the expected role, namely, to obtain a certainty that the judgment is being properly executed.

The implementation of supervision and observation carried out by The Supervision and Observation Judge is reported to the Head of the Court, but not only can determine the policy of guidance for colleagues in the Penitentiary but also there are benchmarks in making decisions by Judges. Besides, to find out that the punishment imposed on Inmates can be useful and whether the implementation of coaching for Inmates who are serving a sentence is based on the human rights of the Inmates, which are aimed at achieving the goals of the Criminal Justice System, and in particular so that the Inmates do not commit crimes again after finished serving his sentence at the Penitentiary (Purnomo, B., 1982). Based on Article 280 of Law No. 8 of 1981, regulates that:

(1) The Judge for supervision and observation shall exercise supervision in order to obtain certainty that the judgment is being properly executed.

(2) The Judge for supervision and observation shall carry out observations to obtain study material in the interest of a beneficial correctness in the imposition of penalties, obtained from the behavior of Inmates or the guidance of the corrections agency and the reciprocal effects on Inmates during the serving of their sentences.

(3) The observation as referred to in section (2) shall be continued after the convicted person has finished serving his sentence.

(4) The supervision and observation as referred to in Article 277 shall also apply to conditional sentences.

Based on Article 281 of Law No. 8 of 1981, regulates that:

"At the request of the Judge for supervision and observation, the Head of the Corrections Agency shall periodically or at any time provide information about the behavior of certain Inmates who are under the observation of said Judge."

Based on Article 282 of Law No. 8 of 1981, regulates that:

"If considered necessary for the sake of effective observation. the Judge for supervision and observation may discuss with the Head of the Corrections Agency methods of guidance for certain Inmates." 
Based on Article 283 of Law No. 8 of 1981, regulates that "the Judge for supervision and observation to the Head of the Court shall report the result of supervision and observation periodically".

From the provisions regarding Judges' supervision on the implementation of Court Decisions, the gap between what the Judge Decides and the actual implementation of sentences in the Penitentiary can be minimized. Besides, The Supervision and Observation Judge can also mediate former Inmates when employed in a Penitentiary. With this role, the Supervision and Observation Judge can follow the development of Inmates and the treatment of Penitentiary Officers to their Inmates.

The existence of The Supervision and Observation Judge in the traffic of Indonesian criminal justice cannot be separated from the need for supervision of the implementation of Court Decisions, as according to Adji, O. S. (1984), that:

"Prosecutors carry out the Decisions of District Courts in criminal cases. However, the "inschackelen" of the head of the Court is a task of supervision to implement the Court's Decision. Supervision was intended to obtain certainty that the judgment is being properly executed."

The Supervision and Observation Judge has a very tough task to put the norms of treatment of these Inmates. Furthermore, if there is a violation, then the Supervision and Observation Judge's role is to resolve it through the Court specifically. Therefore, Reksodiputro, M. (2007) also emphasized that this "burden" must be left to The Senior Supervision and Observation Judge. Against this opinion, the author agrees because, with this seniority, the Supervision and Observation Judge has sufficient sensitivity to evaluate the process being carried out by the Inmates. Because of this heavy-duty, it is not enough that the Supervision and Observation Judge's role is left to Junior Judges who do not have sufficient flight hours. Supervision and observation is a word that looks very simple but has a deep meaning. The supervision carried out by The Supervision and Observation Judge on Inmates by seeing whether there are no rights of the Inmates being violated, and the observation is to see whether the form of punishment imposed on the Inmates can make the Inmates aware when they return to society (Firmansyah, H., 2014).

The Supervision and Observation Judge in guidance for Inmates, especially developments in practice. If we know that to guide Inmates, it is not only the responsibility of The Supervision and Observation Judge as mandated by the Head of the Court, but also the responsibility of the more competent apparatus, namely the officers in the Penitentiary itself, namely the extent to which they conduct guidance to Inmates (Utoyo, M., 2015). Likewise, suppose we pay attention to the description above. In that case, it can be said that the cooperation between The Supervision and Observation Judge and the Head of Penitentiary is what is expected in Law No. 8 of 1981. 
In carrying out the Supervision and Observation Judge's role as the authorized officer in carrying out guidance for Inmates in the Penitentiary, even though The Supervision and Observation Judge is not present or has never provided guidance to, but Penitentiary Officers continue to guide Inmates. By paying attention to the development, guidance for Inmates cannot be said to be an activity of the Supervision and Observation Judge's role because The Supervision and Observation Judge has not carried out their duties as stated in the laws and regulations. Furthermore, the Supervision and Observation Judge is still passive and does not have a separate budget line, nor does they not yet have the staff to deal with the data of the Inmates who are serving their sentence at the Penitentiary.

\section{A. Implementation of the Supervision and Observation Judge's Role in Implementing Court Decisions in the Penitentiary}

\section{Checking on the Spot in the Penitentiary}

As in the previous description, Court decisions were signed by the Prosecutor, Head of the Penitentiary, and Inmates. Therefore, new Inmates who are delegated to the Penitentiary must make an official report on implementing the Court Decision. Prosecutors send it to The Supervision and Observation Judge via Clerk. Furthermore, the junior clerk of the criminal section records in the register supervision and observation book.

This method of checking on the spot is intended to determine whether the Inmates are doing routine and serving their sentences in the Penitentiary or not because it does not rule out the possibility that there are Inmates who should be in the Penitentiary. However, they are free to enter and exit the Penitentiary (Khotimah, K. \& Astuti, P., 2018). As according to one of the Supervision and Observation Judge, that through checking in the spot at the Penitentiary, there are several things the Supervision and Observation Judge wants to know, namely: ${ }^{1}$

a. Supervision of the implementation of Court Decisions in a jurisdiction;

b. Observing the behavior of Inmates who have been given depriving liberty penalties and only in the Penitentiary;

c. Supervision of Inmates who are undergoing conditional release;

d. Supervision of the Inmates who obtained leave towards freedom;

e. Perform supervision and observation of Inmates sent from other penitentiaries.

f. Performing supervision and observation of other District Courts' Decisions because there are no penitentiaries in the District Court's jurisdiction.

${ }^{1}$ Results of Interviews with the Supervision and Observation Judge of the Makassar Class IA District Court, 2016. 
Thus, The Supervision and Observation Judge does not always supervise and observe the implementation of Court Decisions in which he is assigned. However, the Supervision and Observation Judge can supervise and observation of other District Courts' Decisions.

\section{Conducting Observations in the Penitentiary}

Through observations in the Penitentiary, The Supervision and Observation Judge will collect data about Inmates, including the following (Masu, R. R. \& Aloysius, S., 2016):
a. Name;
b. Types of criminal acts committed;
c. time serving a sentence;
d. The state of the household;
e. Family concern for him;
f. The state of the environment;
g. Job history records;
h. Notes about your behavior during undergoing conditional releases;
i. Number of close friends;
j. Important notes of his personality;
k. Psychic condition;
l. The Supervision and Observation Judge's assessment of the implementation of punishment includes:

1) Whether the submission of the Inmates by the Prosecutor to the Head of the Penitentiary is appropriate or not;

2) Whether the implementation of punishment by the Penitentiary Officers is under the correctional system principles or not;

3) Whether the guidance of Inmates by the Penitentiary Officers is under the principles of the correctional system or not; and

4) Does the Penitentiary understand that punishment is intended to provide a deterrent effect but is not allowed to degrading human dignity.

To get accurate data about the personal data of Inmates in the Penitentiary, ideally, The Supervision and Observation Judge should pay more attention to the Inmates, especially by questioning their conditions which include: their health, medical services, their food, their rooms, their safety, the treatment of Penitentiary Officers, and another attention. However, according to one of the Penitentiary Officer, that: ${ }^{2}$

"The Supervision and Observation Judge does not work optimally to approach the Inmates in the Penitentiary. The Supervision and Observation Judge only lists a few Inmates to be used as a sample to serve as a form of accountability to the District Court's Head."

${ }^{2}$ Results of Interviews with the Officer of the Makassar Class I Penitentiary, 2016. 


\section{Conducting Interviews with Penitentiary Officers}

In formal juridical terms, the Supervision and Observation Judge's role is regulated in Article 277 of Law No. 8 of 1981. It should be morally based on the Supreme Court Circular No. 7 of 1985. Besides, the coordination between the Supervision and Observation Judge with the Penitentiary Officers must be as well as possible so that the protection of the Inmates' human rights in the Penitentiary can be implemented properly.

Furthermore, the assimilation process is a form of guidance from the Penitentiary Officers to Inmates, as based on Article 38 section (2) of Government Regulation of the Republic of Indonesia Number 99 of 2012 on the Second Amendment to Government Regulation Number 32 of 1999 on Terms and Procedures for the Exercise of Correctional Assisted Residents Rights (hereinafter referred to as Government Regulation No. 99 of 2012), regulates that:

"The implementation of activities ... is notified in writing to the Regional Government, the Police, and the Supervision and Observation Judge in the local area."

Therefore, according to one of the Supervision and Observation Judge that the importance of conducting interviews with Penitentiary Officers is intended to find out: ${ }^{3}$

a. Guidance results;

b. Behavioral development achieved by Inmates from the guidance process;

c. Setbacks that occur from behavioral and psychological Inmates while serving a sentence at the Penitentiary;

d. The relationship between the Penitentiary Officers and their Inmates; and

e. Human relations between fellow Inmates.

The results of interviews conducted by the Supervision and Observation Judge to Penitentiary Officers showed good results. However, according to one of the Penitentiary Officer, that: ${ }^{4}$

"There is no way I can give a less satisfying answer. It does not mean that I cover up the things that are not good from Inmates' condition. More precisely, I tried to use non-frontal language. This also happened when the Supervision and Observation Judge conducted interviews with the Inmates, where the Inmates also gave satisfying answers to the Supervision and Observation Judge."

Besides, according to one of the Inmates, that: ${ }^{5}$

"When I was interviewed by the Supervision and Observation Judge, I was afraid to give the wrong information. Do not let me be considered

${ }^{3}$ Results of Interviews with the Supervision and Observation Judge of the Makassar Class IA District Court, 2016.

${ }^{4}$ Results of Interviews with the Officer of the Makassar Class I Penitentiary, 2016.

${ }^{5}$ Results of Interviews with the Inmates of the Makassar Class I Penitentiary, 2016. 
to be not well behaved and later do not get a remission. When the Supervision and Observation Judge came to the Penitentiary, he only interviewed a few Inmates, and the interviewing process was not too long, after which he left. Even then, as far as I can remember, the last time he came was about ten months ago."

Thus, it can be Judged that the Supervision and Observation Judge to the Penitentiary is merely carrying out the duties assigned by the Head of the Court. Meanwhile, the Supervision and Observation Judge's role, especially regarding guidance and protection of the Inmates' human rights, has been regulated in Law No. 8 of 1981, Supreme Court Circular No. 7 of 1985, Decree of Minister of Justice of the Republic of Indonesia Number M.02-PK.04.10 of 1990 on Guidance Pattern Inmates/Prisoners (hereinafter referred to as Decree of Minister of Justice No. M.02-PK.04.10 of 1990), Law of the Republic of Indonesia Number 12 of 1995 on Correctional (hereinafter referred to as Law No. 12 of 1995), Government Regulation No. 99 of 2012, and other laws and regulations apply in Indonesia.

\section{B. The Obstacles Implementation of the Supervision and Observation in Implementing Court Decisions in the Penitentiary}

From the results of the researchers, some of the obstacles that occurred as according to one of the Supervision and Observation Judges which were very rare to the Penitentiary were caused by several things, namely: ${ }^{6}$

1. There is an activity in the form of handling cases in Court;

2. The Supervision and Observation Judge is of the view that a visit once every six months is considered too congested in their activities;

3. The Supervision and Observation Judge is of the view that what Penitentiary Officers are doing is quite good;

4. Penitentiary plays a bigger role in enforcing the Human Rights of Inmates.

Meanwhile, according to one of the Penitentiary Officer, that: ${ }^{7}$

"What is an obstacle to carrying out supervision and observation of Inmates is the problem of funding. Suppose the operational budget is still very minimal. In that case, the achievements of the terms and procedures for the exercise of correctional assisted residents' rights will not be realized as expected according to the laws and regulations. Especially for Inmates serving longer sentences, they will experience difficulties in fulfilling their daily needs after being released."

Based on the description above, the more important role in coaching Inmates is the Penitentiary staff, who directly intervenes to conduct coaching for Inmates serving their sentences in the Penitentiary.

${ }^{6}$ Results of Interviews with the Supervision and Observation Judge of the Makassar Class IA District Court, 2016.

${ }^{7}$ Results of Interviews with the Officer of the Makassar Class I Penitentiary, 2016. 
However, from this research, it is obtained information from several Supervision and Observation Judge and the Head of Penitentiary, where it is concluded that the role of The Supervision and Observation Judge is not only to provide guidance but to conduct direct interviews with both the Inmates and the Penitentiary Officers. The Supervision and Observation Judge's role also observes the conditions, atmosphere, and activities in the Penitentiary. Thus, on that basis, the relationship between the Head of the Penitentiary and The Supervision and Observation Judge needs to be intensified. It is hoped that this meeting can form a strategy and tactics regarding the supervision and observation methods and the guidance for Inmates. So that guidance for Inmates is both supervision and observation carried out by The Supervision and Observation Judge on Inmates in the Penitentiary can run more perfectly as regulated in-laws and regulations.

Under the description above what has been put forward by The Supervision and Observation Judge and the Head of Penitentiary, the author also considers that the coaching carried out by Penitentiary Officers and The Supervision and Observation Judge needs to make a guide so that The Supervision and Observation Judge is not every day supervise and observe the implementation of the sentencing verdict against his Inmates. However, at the very least, as based on the Supreme Court Circular No. 7 of 1985, regulates that:

"The Supervision and Observation Judge conducts a check on the spot at least once every three months to the Penitentiary to check the accuracy of the minutes of implementing Court Decisions signed by the Prosecutor, Head of Penitentiary, and Inmates."

Based on Article 3 of Law No. 12 of 1995, regulates that:

"The correctional system functions to prepare Correctional Assisted Residents so that they can integrate healthily with the community, so that they can play a role again as free and responsible members of society."

The Correctional System is a series of units in the enforcement of criminal law. Therefore its implementation cannot be separated from the development of a general conception of punishment. Inmates are not only objects but also subjects that are no different from other human beings who can sometimes make mistakes that can be subject to punishment, so they do not have to be eradicated. What must be eradicated are factors that can cause Inmates to do things against the law, morality, religion, or other social obligations subject to criminal law. Criminalization is an effort to make Inmates feel sorry for their actions, return to being good citizens, obeying the law, upholding moral, social, and religious values to achieve a safe, orderly and peaceful community life. Universally, it can be said that the main function of law is to control social life by balancing the interests that exist in society or, in other words, as a means of social control. 
On the other hand, if we focus on the law's operationalization aspects, it will discuss the effectiveness and good law, where the discussion cannot be separated from the legal culture. Every legal system always contains three components with the core of legal culture, namely a structural component, a substantive component, and a cultural component.

The structural and legal system components include the various institutions, forms, and processes created by the legal system with various functions to support the legal system's operation (Begem, S. S., Qamar, N., \& Baharuddin, H., 2019). One such institution is the Court. Let us look at the operation of law solely from a structural aspect. We will be fixated on the framework for the legal system's functioning as regulated in the applicable laws and regulations in Indonesia. Likewise, suppose you only look at it from a substantive perspective. In that case, the law will appear as a logical, consistent, and autonomous set of norms. In the end, the law is only seen as something that dogmatizes in nature so that social reality is forgotten. The structural and substantive components will be largely determined by the legal culture in which these components are located.

The acceptance, registration, and placement of Inmates at the Penitentiary have been regulated in the Decree of Minister of Justice No. M.02-PK.04.10 of 1990. This regulation's essence is that acceptance of new Inmates at the Penitentiary must be based on valid documents, particularly a warrant/determination detention. Besides, Penitentiary Officers record the identity and take fingerprints of Inmates and adapt them to their warrant/determination detention, and take photos of their Inmates for the sake of upholding the law to realize truth and justice.

To achieve the objectives mentioned above, the Prosecutor's Office needs to coordinate with all components of law enforcement agencies, including Courts and penitentiaries. This is very necessary considering the Penitentiary also determines the success or failure of the Criminal Justice System's objectives as a whole.

This coordination is needed to intend that every policy related to the judicial process should be informed or coordinated with the correctional institution. For example, a change from suspect/defendant status to Inmates status or Inmates status to Inmates is freed according to law, or the defendant is freed from all demands. According to one of the Penitentiary Officer, that: ${ }^{8}$

"Lack of coordination between the Prosecutor and the Penitentiary, so that many changes in detainees' status are not known. Likewise, the Court did not send a statement of its decision to the Penitentiary."

Meanwhile, according to one of the Supervision and Observation Judge, that "in conducting supervision and observation with Inmates in the Penitentiary, we randomly select 10-15 Inmates and interview them". ${ }^{9}$

\footnotetext{
${ }^{8}$ Results of Interviews with the Officer of the Makassar Class I Penitentiary, 2016.

${ }^{9}$ Results of Interviews with the Supervision and Observation Judge of the Makassar Class IA District Court, 2016.
} 
Furthermore, according to the Head of the Penitentiary, that: ${ }^{10}$

"The Supervision and Observation Judge's role in supervision and observation of the implementation of Court decisions as regulated in Articles 277 to 283 of Law No. 8 of 1981, basically it has not been described to what extent the authority of The Supervision and Observation Judge on a Court decision."

Based on the description above, it can be concluded that the Supervision and Observation Judge's role in carrying out supervision and observation of Court decisions still requires more specific implementing regulations, so obtain a certainty that the judgment is being properly executed and under the laws and regulations in Indonesia.

\section{CONCLUSION AND RECOMMENDATION}

Based on the description of the results and discussion, it can be concluded that the implementation of the role of the Supervision and Observation Judge in the implementation of the decision of the Makassar Class IA District Court at the Makassar Class I Penitentiary has not run optimally, because between The Supervision and Observation Judge and the Head of the Penitentiary rarely meet and discuss guidance issues for Inmates at the Penitentiary. The obstacles in implementing the role of the Supervision and Observation Judge at the Penitentiary include the problem of insufficient funds available for operational supervision and observation and the absence of special staff to assist the Supervision and Observation Judge in recording their Inmates. Based on these conclusions, more specific implementing regulations are needed to certify that the judgment is being properly executed and under the laws and regulations in Indonesia. Furthermore, there is a need for effective cooperation between the Court (The Supervision and Observation Judge) and the Penitentiary (Penitentiary Officers), who must always coordinate as one unit in an integrated Criminal Justice System.

\section{REFERENCES}

Adji, O. S. (1984). Hukum (Acara) Pidana dalam Prospeksi. Jakarta: Erlangga.

Begem, S. S., Qamar, N., \& Baharuddin, H. (2019). Sistem Hukum Penyelesaian Pelanggaran Hak Asasi Manusia (HAM) Berat Melalui Mahkamah Pidana Internasional. SIGn Jurnal Hukum, CV. Social Politic Genius (SIGn), 1(1), pp. 1-17. doi: https://doi.org/10.37276/sjh.v1i1.28

Circular of the Supreme Court of the Republic of Indonesia Number 7 of 1985 on Task Implementation Instructions of the Supervision and Observation Judge.

Decree of Minister of Justice of the Republic of Indonesia Number M.02-PK.04.10 of 1990 on Guidance Pattern Inmates/Prisoners.

\footnotetext{
${ }^{10}$ Results of Interviews with the Head of the Makassar Class I Penitentiary, 2016.
} 
Dewi, A. A. I. M. C. (2012). Perlindungan Hukum terhadap Korban Penyalahguna Narkotika dengan Berlakunya Undang-Undang Nomor 35 Tahun 2009 tentang Narkotika. Jurnal Magister Hukum Udayana (Udayana Master Law Journal), Universitas Udayana, 1(1), pp. 77-88. doi: https://doi.org/10.24843/JMHU.2012. v01.i01.p01

Firmansyah, H. (2014). Peran Hakim Pengawas dan Pengamat sebagai Penilai Perilaku Narapidana di Lembaga Pemasyarakatan. Jurnal Hukum Prioris, Universitas Trisakti, 4(2), pp. 115-130.

Government Regulation of the Republic of Indonesia Number 32 of 1999 on Terms and Procedures for the Exercise of Correctional Assisted Residents Rights. (State Gazette of the Republic of Indonesia of 1999 Number 69, Supplement to the State Gazette of the Republic of Indonesia Number 3846).

Government Regulation of the Republic of Indonesia Number 28 of 2006 on Amendment to Government Regulation Number 32 of 1999 on Terms and Procedures for the Exercise of Correctional Assisted Residents Rights. (State Gazette of the Republic of Indonesia of 2006 Number 61, Supplement to the State Gazette of the Republic of Indonesia Number 4632).

Government Regulation of the Republic of Indonesia Number 99 of 2012 on the Second Amendment to Government Regulation Number 32 of 1999 on Terms and Procedures for the Exercise of Correctional Assisted Residents Rights. (State Gazette of the Republic of Indonesia of 2012 Number 225, Supplement to the State Gazette of the Republic of Indonesia Number 5359).

Khotimah, K. \& Astuti, P. (2018). Pelaksanaan Pengawasan Putusan Pengadilan di Gresik Jawa Timur. Novum: Jurnal Hukum, Universitas Negeri Surabaya, 5(4), pp. 1-9.

Law of the Republic of Indonesia Number 8 of 1981 on the Code of Criminal Procedure. (State Gazette of the Republic of Indonesia of 1981 Number 76, Supplement to the State Gazette of the Republic of Indonesia Number 3209).

Law of the Republic of Indonesia Number 12 of 1995 on Correctional. (State Gazette of the Republic of Indonesia of 1995 Number 77, Supplement to the State Gazette of the Republic of Indonesia Number 3614).

Law of the Republic of Indonesia Number 48 of 2009 on the Judicial Powers. (State Gazette of the Republic of Indonesia of 2009 Number 157, Supplement to the State Gazette of the Republic of Indonesia Number 5076).

Mahmud, Y., et al. (2019). Restorative Justice dalam Putusan Hakim Nomor: 31/Pid. Sus/2018/PN.Lbto Atas Kasus Persetubuhan terhadap Anak. SIGn Jurnal Hukum, CV. Social Politic Genius (SIGn), 1(1), pp. 52-69. doi: https://doi.org/10.37276/ sjh.v1i1.37

Masu, R. R. \& Aloysius, S. (2016). Model Pemberdayaan Hakim Pengawas dan Pengamat Berbasis Koordinasi dalam Mewujudkan Pengarusutamaan Hak Anak (PUHA) di Lapas Anak Kelas IIA Kupang Lembaga Pembinaan Khusus Anak Kupang (LPKA). Jurnal Paradigma Hukum Pembangunan, Universitas Katolik Atma Jaya, pp. 224238. 
Mys. (2011, May 11). Hapuskan Hakim Wasmat dari KUHAP. In Hukum Online. Retrieved from https://www.hukumonline.com/berita/baca/lt4dca6876d8a69/ hapuskan-hakim-wasmat-dari-kuhap/, at the date on December 27, 2019.

Nasrullah, N. (2020). Putusan Hakim terhadap Pemberian Sanksi di Bawah Batas Minimal pada Tindak Pidana Narkotika. SIGn Jurnal Hukum, CV. Social Politic Genius (SIGn), 2(1), pp. 1-19. doi: https://doi.org/10.37276/sjh.v2i1.59

Pratama, W. A. (2019). Penegakan Hukuman Mati terhadap Pembunuhan Berencana. SIGn Jurnal Hukum, CV. Social Politic Genius (SIGn), 1(1), pp. 29-41. doi: https:// doi.org/10.37276/sjh.v1i1.34

Purnomo, B. (1982). Pokok-Pokok Hukum Acara Pidana dan Beberapa Harapan dalam Pelaksanaan Kitab Undang-Undang Hukum Acara Pidana. Yogyakarta: Liberty.

Qamar, N., et al. (2017). Metode Penelitian Hukum (Legal Research Methods). Makassar: CV. Social Politic Genius (SIGn).

Reksodiputro, M. (2007). Hak Asasi Manusia dalam Sistem Peradilan Pidana. Jakarta: Pusat Pelayanan Keadilan dan Pengabdian Hukum, UI Press.

Sampara, S. \& Husen, L. O. (2016). Metode Penelitian Hukum. Makassar: Kretakupa Print.

Soepiadhy, S. (2008). Meredesain Konstitusi: Pembangkangan Seorang Anak Bangsa Untuk Demokrasi. Jakarta: Burungmerak Press.

Suhariyanto, B. (2017). Kedudukan Perdamaian sebagai Penghapus Pemidanaan Guna Mewujudkan Keadilan dalam Pembaruan Hukum Pidana. Jurnal Rechts Vinding: Media Pembinaan Hukum Nasional, Kementerian Hukum dan Hak Asasi Manusia RI, 6(1), pp. 1-19. doi: http://dx.doi.org/10.33331/rechtsvinding.v6i1.127

Suherman, A. (2019). Implementasi Independensi Hakim dalam Pelaksanaan Kekuasaan Kehakiman. SIGn Jurnal Hukum, CV. Social Politic Genius (SIGn), 1(1), pp. 42-51.

Susansi, E. (2019). Fungsi Pengawasan Hakim Pengawas dan Pengamat terhadap Pembinaan Warga Binaan. Indonesian Journal of Criminal Law, Institute for Learning Innovation and Counseling, 1(2), pp. 77-88. doi: https://doi. org/10.31960/ijocl.v1i2.298

Syamsudin, M. (2011). Rekonstruksi Pola Pikir Hakim dalam Memutuskan Perkara Korupsi Berbasis Hukum Progresif. Dinamika Hukum, Universitas Jenderal Soedirman, 11(1)

Taufiq, A. I. (2016). Pelaksanaan Tugas Hakim Pengawas dan Pengamat Pengadilan Negeri Yogyakarta bagi Narapidana Penjara di Lapas Wirogunan dan Lapas Narkotika. Supremasi Hukum: Jurnal Kajian Ilmu Hukum, Universitas Islam Negeri Sunan Kalijaga Yogyakarta, 5(2), pp. 143-167.

Tjahjati, E. (2012). Perlindungan dan Pembinaan terhadap Warga Binaan Pemasyarakatan (WBP) (Study di Lembaga Pemasyarakatan Anak Klas IIA Blitar). Mizan: Jurnal Ilmu Hukum, Universitas Islam Kadiri, 1(2), pp. 55-62. 
Utoyo, M. (2015). Konsep Pembinaan Warga Binaan Pemasyarakatan Analysis of Prisoners Guidance to Reduce Level. Pranata Hukum, Universitas Bandar Lampung, 10(1), pp. 37-48.

I Yafid, B. M. \& Muzakkir, A. K. (2020). The Role of the Supervision and Observation Judge I on Guidance for Inmates. Sovereign: International Journal of Law, CV. Social Politic Genius I (SIGn), 2(2), pp. 40-56. doi: https://doi.org/10.37276/sijl.v2i2.33 